This item was submitted to Loughborough's Research Repository by the author.

Items in Figshare are protected by copyright, with all rights reserved, unless otherwise indicated.

\title{
Developing professional competencies for humanitarian engineers
}

PLEASE CITE THE PUBLISHED VERSION

http://dx.doi.org/10.1680/jcien.15.00046

\section{PUBLISHER}

(C) ICE

\section{VERSION}

AM (Accepted Manuscript)

\section{PUBLISHER STATEMENT}

This work is made available according to the conditions of the Creative Commons Attribution-NonCommercialNoDerivatives 4.0 International (CC BY-NC-ND 4.0) licence. Full details of this licence are available at: https://creativecommons.org/licenses/by-nc-nd/4.0/

\section{LICENCE}

CC BY-NC-ND 4.0

\section{REPOSITORY RECORD}

Reed, Brian, and Emily Fereday. 2019. "Developing Professional Competencies for Humanitarian Engineers". figshare. https://hdl.handle.net/2134/20965. 


\section{Developing professional competencies for humanitarian engineers}

Author 1

- Brian Reed BSc (Hons)(Dunelm), PGDip (Lond), MSc (N'cle), CEng, CEnv, C.WEM, MICE, MCIWEM, FHEA

- Water, Engineering and Development Centre (WEDC), School of Civil and Building Engineering, Loughborough University, Loughborough UK

Author 2

- Emily Fereday MA (Oxon), MSc (SOAS), PGCE (Oxford)

- Country Director UK/ Europe Programme, RedR London UK

Full contact details of corresponding author.

Brian Reed, Lecturer,

Water, Engineering and Development Centre (WEDC)

School of Civil and Building Engineering

The John Pickford Building

Loughborough University

Leicestershire LE11 3TU UK

b.j.reed@Lboro.ac.uk

\section{Abstract}

One of the roles of Engineering Institutions is the registration and regulation of engineering professionals, assessing their competence in both technical and management areas. Engineers are required to work within their area of competence, so, for example an experienced water treatment engineer may hesitate to do major structural design if they are not able to do this to a professional standard. A similar approach has is being promoted for professional humanitarian workers, identifying core competencies relevant to emergency relief work. This would improve standards in the workforce, allow training and experience to be independently evaluated and facilitate the careers of people working in a very mobile sector. Thus a professional engineer working in this area should be able to demonstrate both their engineering competence and their adherence to Core Humanitarian Standards. However there is an additional area that requires attention, namely the specific engineering techniques that relate to disaster relief. . Using the experiences of RedR UK in recruiting members and training humanitarians, this paper explores the skills, knowledge and other attributes that distinguish an enthusiastic but ill-informed and inexperienced person from somebody with the expertise to work efficiently, effectively and ethically in a challenging humanitarian context.

Keywords chosen from ICE Publishing list

Codes of practice \& standards; Disaster engineering; Education \& training 


\section{Introduction}

\subsection{Civil Engineering institutions}

In 1818, young engineers founding the Institution of Civil Engineers (ICE) complained the profession was weakened because “'unskilled and illiterate persons' were presenting themselves as engineers: 'engineering in England is taught only as a trade and this is the essential cause of the evil complained of'" (Ferguson and Chrimes, 2011). The subsequent Royal Charter noted:

“... important and public and private works and services in the United Kingdom and overseas which contribute to the wellbeing of mankind are dependent on Civil Engineers and call for a high degree of professional knowledge and judgment in making the best use of scarce resources in care for the environment and in the interests of public health and safety it is accordingly of importance that there should be a ready means as heretofore of ascertaining persons who by proper training and experience are qualified to carry out such works."

ICE 2014

"Proper training and experience" is a requirement for individuals, as professional conduct guidance states:

- "Members must be competent in relation to every project that they undertake. They must ensure that, having regard to the nature and extent of their involvement in a project, they have the relevant knowledge and expertise. ...

- Being competent means that members have ensured that their knowledge has remained up to date, and has covered all relevant developments; in other words, members must maintain structured programme of continuing professional development to improve and update their technical knowledge."

ICE 2014

\subsection{The evolution of the profession}

Defining the profession, civil engineering is

"the art of:

- $\quad$ working with the great sources of Power in Nature

- for the use and benefit of society'"

(Tredgold 1828 adapted by Jowitt 2004 [authors' emphasis])

Thus there is a technical and a socio-economic or human dimension.

Jowitt (2004) noted waves of technological changes and also developments in society (e.g. from subsistence to urban societies), driven by or driving the technological change. The original institution was broad; but specialisation began when the Institution of Mechanical Engineers was founded in 1846, followed by the Institute of Naval Architects, Institution of Gas Engineers, the Iron and Steel Institute, the Association of Municipal and Sanitary Engineers and Surveyors (forerunner of the Institution of Municipal Engineers who later merged with the ICE), the Society of Telegraph Engineers (forerunner of the Institution of Electrical Engineers), the Institute of Sanitary Engineers (later the Institution of Public Health Engineers), the British Association of Waterworks Engineers (later the Institution of Water Engineers, who merged with the Institute of Water Pollution Control to form the [Chartered] Institution of Water and Environmental Management). The 
Concrete Institute (later the Institution of Structural Engineers) started in 1908 (Ferguson and Chrimes, 2011). There is a pattern of professions broadening to cater for technical and social change until a new specialism is created, with distinct knowledge and expertise.

\section{Changing the social context}

One socially distinct area is 'development engineering' - supporting international development and poverty reduction in low-income countries (EWB, nd). Development engineering has specific technical solutions such as pit latrines, handpumps or unpaved roads, but to focus on technology misses larger differences in the expertise required. The knowledge of the distinct socio-economic context differentiates the development engineer from fellow professionals working in other contexts. Development engineering takes place in a resource-poor environment - encompassing institutional and human resource capacity as well as economics. 'Appropriate technology' matches technology to the context, not just using a standard low-cost solution (Carr, 1985). This societal challenge is as complex as a new technical field and therefore requires expertise.

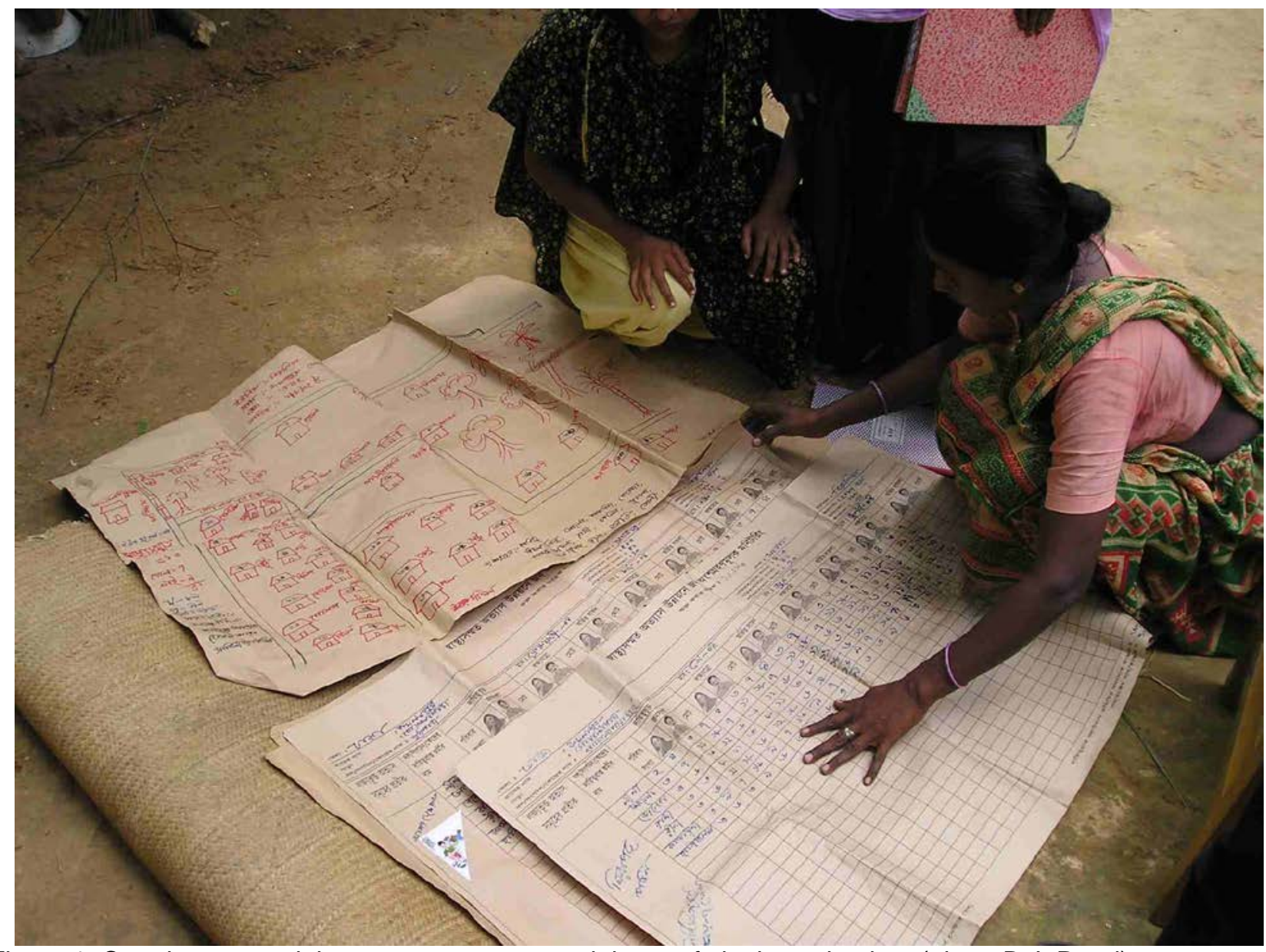

Figure 1. Carrying out social surveys are an essential part of site investigation. (photo B.J. Reed)

Bourn and Neal (2008) tried promoting the societal aspects of engineering (labelling it "global engineering") such as human rights, diversity, inclusivity and responsibility within the profession but observed tension between depth and breadth of expertise, along with a perception that "social and environmental dimensions of engineering were less academically rigorous". They noted introducing new issues into existing engineering degrees met with: 
“... notable constraints which inhibit curriculum change such as an already crowded curriculum, funding constraints... a lack of relevant experience and knowledge amongst some teaching staff and resistance to any dilution of core engineering content"

\subsection{Disasters and humanitarian relief}

Technical and social development does not always move forwards. Disasters, natural and man-made, can set back development so people are faced with basic survival, requiring a fast humanitarian response. The need for qualified engineers is clear; water supply is just as vital in controlling epidemics as the work of medics. The consequences of failure or inefficiency are high. "Engineering in Emergencies" (Davis and Lambert, 2002) demonstrates context-specific technologies similar to development engineering but the societal context is distinct from development. Engineering responsibilities are broad, not just core areas such as water, structures or roads, but sanitation comprising excreta disposal, drainage and solid waste management (including healthcare waste, menstrual hygiene materials and dead bodies). Limited resources include working without the support of fellow engineers to check designs or provide advice, as well as material shortages and a lack of information. Liaising with other agencies, training staff and managing projects stretch the skill-set further.

Beside the technical knowledge, humanitarian relief adds another dimension. Engineering, like medicine or education, responds to the needs of humanity, but whilst all civil engineering could be seen as humanitarian, Humanitarian Agencies have specific operational requirements, adhering to the Humanitarian Charter, believing that "action should be taken to prevent or alleviate human suffering arising out of disaster or conflict, and that nothing should override this principle." (Sphere2011). This ethical position is part of a specific definition of Humanitarian work, with requirements on professionals providing relief, beyond normal professional codes of conduct. This nuance has echoes of the distinction between professional engineers and the person who repairs machinery that has been going on since 1818. Thus the "Humanitarian engineer" is distinct from development engineering and the wider profession both in terms of technical expertise and ability to work in the specific context relating to emergency or disaster relief.

\subsection{The need for expertise}

Humanitarian crises make the requirement for competent staff critical. Jan Egland, former UN UndersecretaryGeneral for Humanitarian Affairs and Emergency Relief Coordinator, noted:

"There were instances where the response was untested, chaotic, amateurish, doubled up, overlapping, done by "Mom and Pop" operations. ... Because if you're not a professional in this game, you have no right to descend on someone in their moment of crisis and do on-the-job training. Saving human lives is no place for amateurs. Why is that? Because the poor, dispossessed and disaster-prone should have at least one basic right left to them: to be protected from incompetence." 
Employing experts is not straightforward. Humanitarian workers are often on short-term contracts, as agencies may have limited long-term budgets. Agencies adjust staffing to meet fluctuating workloads and changes of location. Staff live away from home in arduous conditions, moving both geographically and between agencies, making long-term employment (and a career) difficult. Employee turnover rates can be high, with less than half of a workforce re-enlisting after their first mission (Korff et al, 2015)

Agencies try to employ local staff. RedR UK's strategy is have $90 \%$ of the people they train being national staff (i.e. responding to emergencies in their own country). They are usually the first to respond, understand the local context, are permanently based in the area and can follow the operation from immediate relief through to longer-term rebuilding. Their employment can help economic recovery locally, but at an international scale they are not necessarily available or prepared to respond to disasters elsewhere, so the local training process has to be repeated.

New national or international staff may not have the right skills but while there is growing acknowledgement of the need for training in advance of emergencies, it remains challenging to fund. There are longer courses but these are costly, so are a commitment, especially for young professionals who may not pursue a career in this area. Often there may be no training or no agreement on what the qualifications should be.

“ ... where consistent humanitarian occupational standards do not exist, several NGOs, INGOs, learning providers and universities have unilaterally moved, ... to address the learning and capacity building needs of workers based on their particular interpretations of identified needs. This has led to an ad hoc training offering, with gaps in provision and a lack of pathways and progression routes ..., both for those wishing to enter the sector and those wishing to develop professionally within the sector.

(Walker and Russ, 2010). 


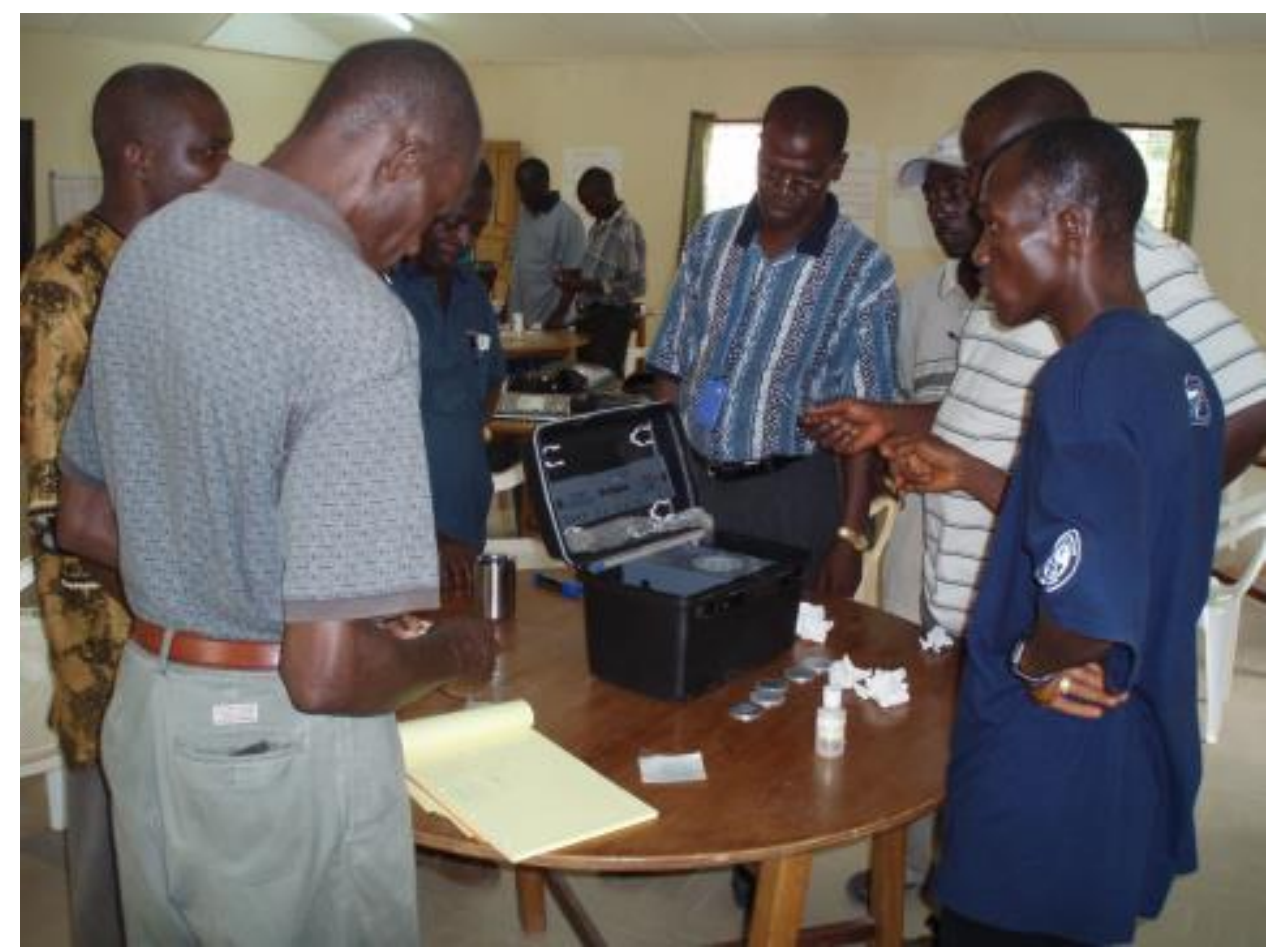

Figure 2. Disaster preparedness training, Liberia (photo B.J. Reed)

Even if 'technical' qualifications are available, this may not reflect the humanitarian context, as

"the ... complexities that exist in the humanitarian sector include the interface of a variety of professions; medical, engineering, logistical, security and others all coming with their own affiliations to professional bodies ... but often missing the core competencies deemed necessary to be fit to operate in the humanitarian field. ... There is a need to ensure that ... support systems are fit for purpose and serving beneficiaries in as efficient a way as possible."

(Walker and Russ, 2010).

\section{Professionalising humanitarian action}

The Sphere project (Sphere 2011) agreed standards that agencies should aim for in humanitarian relief, but the outputs of aid depend on inputs, such as competent staff.

"Following a decade in which the humanitarian sector has sought to develop global standards, codes and representative bodies, there is ... momentum ... for creating a unified system of professional development, ... which could increase accountability, raise the quality and consistency of humanitarian service, open up the profession to talented new recruits, and raise the status of the humanitarian service provider to a level on a par with other professional groups. This would support ... career paths ... and ... retention of humanitarian workers ... This also prepares for the forecasted increases in natural and complex disasters ..."

(Walker and Russ, 2010).

In 2014, a Core Humanitarian Standard on Quality and Accountability was produced to improve the quality and effectiveness of assistance. Two of the standards reinforce the need for capacity building of staff:

"Standard 7: Humanitarian actors continually learn and improve 
Standard 8: Staff are supported to do their job effectively, and are treated fairly and equitably" (CHS 2014).

\subsection{Defining competent professionals}

The founders of the ICE knew they were not experts compared with experienced practitioners but these young men did have some knowledge and skills; they developed these together, sharing successes and failures with their peers. A professional's development has two stages, firstly gaining knowledge and skills (learning) and then putting these into action (performance) (figure 3). Competency is a minimum requirement of putting knowledge into practice rather than expertise and long experience.

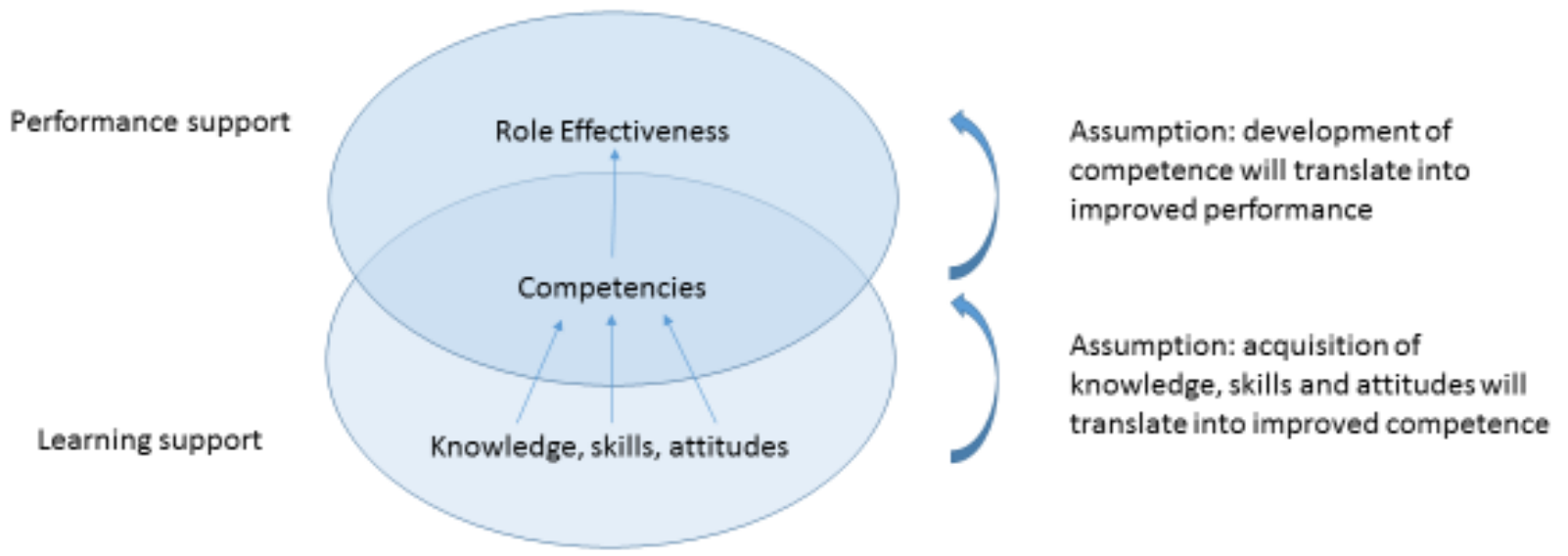

RedR UK Theory of Professional Development

Figure 3. RedR UK Theory of Professional Development.

\subsubsection{Qualifications}

The Geneva Centre for Education and Research in Humanitarian Action (CERAH) courses on humanitarian or refugee studies (Rainhorn et al 2010) but did not include in nutrition, nursing or engineering for disasters.

These courses address the Humanitarian aspects but do not necessarily prepare somebody for the technical aspects of relief. EUPHRA (European Universities on Professionalisation on Humanitarian Action) developed a qualifications framework, looking at the knowledge, skills and competencies required (Aardema and Muguruza, 2014) under six themes:

- Humanitarian commitment

- Context analysis \& reflection

- Coping \& safety

- Leadership

- Collaborative relationships

- Service to crisis-affected people 
The EUPHRA framework took professional competency as the starting point to see what humanitarian organisations wanted, as curricula should be aligned with field requirements (Reed et al 2011), but again focused on the generic humanitarian themes.

\subsubsection{Experience}

Qualifications are only part of the picture. They provide theory, knowledge and skills, but performance is key in vocational subjects. PHAP (Professionals in Humanitarian Assistance and Protection) is a "cross-sector professional association of individuals" with roots in humanitarian law and policy (PHAP nd). They require:

"two years of relevant professional experience [which is] ... engagement that has contributed directly or indirectly to the deployment of humanitarian assistance and protection activities ..., such as planning of operations, implementation of programs, evaluation of programs, management of humanitarian operations and/or organizations, engagement in legal and policy developments, as well as advocacy work pertaining to humanitarian assistance and protection... with recognized humanitarian agencies, NGOs, governments, or academic and policy centers ... to which the individual was accountable to an institutional hierarchy in the implementation of professional standards."

"Volunteer work may be accounted for, to the extent this ... was part of a recognized professional organization."

(PHAP nd)

Professionalism is associated with employment but is not necessarily caused by employment. Some experienced, knowledgeable people may volunteer whilst others employed as professionals may lack skills. Volunteering can be a way of gaining experience, providing a route into permanent posts.

\subsubsection{Knowledge into action}

Professionalism is more than time serving or passing exams. The ICE developed work-based attributes, which are "how you carry out your duties and the characteristics that you will need to display", for example "Exercise sound independent judgement and take responsibility" rather than just "knowing" about a topic. These attributes are designed to "... [bridge] the gap between ...education and professional qualifications." and are in three stages:

1. "Knowledge - a basic understanding and knowledge of the attribute and how you achieve it

2. Experience - achieving the attribute in different situations, working under supervision

3. Ability - achieving the attribute in different situations, assisting others and working unsupervised"

(ICE 2015)

The engineer then needs to show full competence in the attributes, gained through application (see figure 4). 


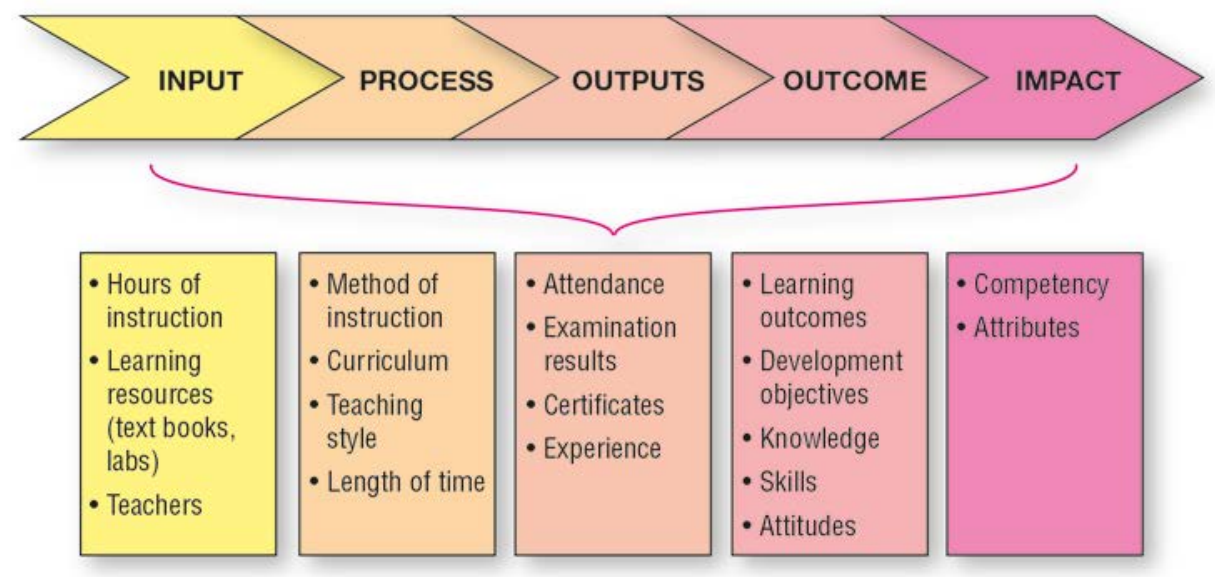

Figure 4. Results chain applied to training and professional development (source WEDC)

Competencies can be seen as indicators of overall performance both in terms of topic and in the level of attainment expected, but they are "regular demonstration of ability" not defined by outcomes (ICE Capacity Building Panel, 2011).

\subsection{Creating humanitarian competencies}

In 2009, ELRHA (Enhancing Learning and Research for Humanitarian Assistance) commissioned a study on "Professionalising the Humanitarian Sector" (Walker and Russ, 2010). This made 13 recommendations relating to professionalisation, for individuals' careers and trainers delivering courses and qualifications, with an emphasis on equitable international access. The report included draft humanitarian competencies. The Consortium of British Humanitarian Agencies (CBHA), which later became the Start Network, led by Action Aid, produced a competency framework (Rutter et al 2011), based on additional research (table 1) to support staff development. The Start Network developed a nine month management and leadership skills development programme, mostly by self-study, group work and coaching with two short workshops, that is self-assessed (Emmens et al, no date). However, the CBHA framework "only articulates core humanitarian behaviours. There are certainly many generic (or non-humanitarian specific) competencies which it is assumed agencies already reference or use." (Rutter et al 2011, emphasis added).

Table 1 The CBHA Humanitarian Competencies and Core Behaviours

\begin{tabular}{|c|c|c|c|c|c|}
\hline $\begin{array}{l}\text { Understanding } \\
\text { of humanitarian } \\
\text { contexts and } \\
\text { application of } \\
\text { humanitarian } \\
\text { principles } \\
\text { Issues/ practices } \\
\text { impacting } \\
\text { current/ future } \\
\text { humanitarian } \\
\text { interventions }\end{array}$ & $\begin{array}{l}\text { Achieving } \\
\text { results } \\
\text { effectively } \\
\text { Behaviours to } \\
\text { use resources } \\
\text { efficiently/ } \\
\text { effectively to } \\
\text { achieve results, } \\
\text { considering the } \\
\text { need for speed/ } \\
\text { scale/ quality }\end{array}$ & $\begin{array}{l}\text { Developingl } \\
\text { maintaining } \\
\text { collaborative } \\
\text { relationships } \\
\text { Behaviours to } \\
\text { develop/ } \\
\text { maintain } \\
\text { collaborative, } \\
\text { coordinated } \\
\text { relationships at } \\
\text { times of } \\
\text { heightened } \\
\text { complexity/ risk }\end{array}$ & $\begin{array}{l}\text { Operating } \\
\text { safelyl } \\
\text { securely in a } \\
\text { humanitarian } \\
\text { response } \\
\text { Behaviours } \\
\text { required to } \\
\text { operate safely } \\
\text { in a pressured } \\
\text { environment }\end{array}$ & $\begin{array}{l}\text { Managing } \\
\text { yourself in a } \\
\text { pressured } \\
\text { changing } \\
\text { environment } \\
\text { Behaviours } \\
\text { required to } \\
\text { operate } \\
\text { effectively within } \\
\text { a humanitarian } \\
\text { context }\end{array}$ & $\begin{array}{l}\text { Leadership in } \\
\text { humanitarian } \\
\text { response } \\
\text { Seeing the } \\
\text { overall goal } \\
\text { within the } \\
\text { changing } \\
\text { context. Taking } \\
\text { responsibility to } \\
\text { motivate others, } \\
\text { independent of } \\
\text { one's role/ } \\
\text { function/ } \\
\text { seniority. }\end{array}$ \\
\hline
\end{tabular}




\begin{tabular}{|c|c|c|c|c|c|}
\hline $\begin{array}{l}\text { Humanitarian } \\
\text { context } \\
\text { Applying } \\
\text { humanitarian } \\
\text { standards / } \\
\text { principles }\end{array}$ & $\begin{array}{l}\text { Programme } \\
\text { quality } \\
\text { Accountability } \\
\text { Decision } \\
\text { making } \\
\text { Impact }\end{array}$ & $\begin{array}{l}\text { Listening/ } \\
\text { dialogue } \\
\text { Working with } \\
\text { others }\end{array}$ & $\begin{array}{l}\text { Security } \\
\text { context/ } \\
\text { analysis } \\
\text { Personal } \\
\text { safety/ security } \\
\text { Minimising risk } \\
\text { to } \\
\text { communities/ } \\
\text { partners }\end{array}$ & $\begin{array}{l}\text { Resilience } \\
\text { Maintaining } \\
\text { professionalism }\end{array}$ & $\begin{array}{l}\text { Self-awareness } \\
\text { Motivating and } \\
\text { influencing } \\
\text { others } \\
\text { Critical } \\
\text { judgement }\end{array}$ \\
\hline
\end{tabular}

Source: Rutter et al 2011 (abridged)

Whilst organisational and academic initiatives are heading in the same direction, they appear to be parallel rather than integrated. This is partly due to the timescales involved. Organizations need to improve the performance of their current staff (using competencies); universities are preparing the next generation (using qualifications). Current initiatives focus on humanitarian rather than engineering issues. Professional bodies work at both these timescales and aspects of competence, taking the overview of a complete career.

\subsection{Humanitarian, functional and specialist competencies}

Core competencies provide a step towards defining the humanitarian profession but assume "generic (or nonhumanitarian specific) competencies" (noted by Rutter et al 2011) are present. There are two aspects to nonhumanitarian competencies.

One aspect relates to the 'function' of a professional, so managers have different skills to trainers, but managers in engineering may share skills with managers in, say, the health sector. These generic or transferable aspects relate to communication, personal attitudes or teamwork. Engineers will be familiar with the generic functional skills required for professional competence, with different levels for technicians, incorporated engineers and chartered engineers (categories C, D and E in table 2). In the humanitarian context, these three levels roughly correspond to field-level workers (up to 18 months' experience), team supervisors (2-5 years' experience) and national/ international level technical staff (over 5 years' experience) (Walker and Russ, 2010).

Table 2 Engineering Competence and Commitment Standards

\begin{tabular}{|l|l|l|l|}
\hline & Engineering Technicians. & Incorporated Engineers. & Chartered Engineers. \\
\hline A & $\begin{array}{l}\text { Use engineering knowledge and } \\
\text { understanding to apply technical } \\
\text { and practical skills. }\end{array}$ & $\begin{array}{l}\text { Use a combination of general and } \\
\text { specialist engineering knowledge } \\
\text { and understanding to apply existing } \\
\text { and emerging technology. }\end{array}$ & $\begin{array}{l}\text { Use a combination of general } \\
\text { and specialist engineering } \\
\text { knowledge and understanding } \\
\text { to optimise the application of } \\
\text { existing/ emerging technology. }\end{array}$ \\
\hline B & $\begin{array}{l}\text { Contribute to the design, } \\
\text { development, manufacture, } \\
\text { construction, commissioning, } \\
\text { operation or maintenance of } \\
\text { products, equipment, processes, } \\
\text { systems or services. }\end{array}$ & $\begin{array}{l}\text { Apply appropriate theoretical/ } \\
\text { practical methods to design, } \\
\text { develop, manufacture, construct, } \\
\text { commission, operate, maintain, } \\
\text { decommission and re-cycle } \\
\text { engineering processes, systems, } \\
\text { services and products. }\end{array}$ & $\begin{array}{l}\text { Apply appropriate theoretical } \\
\text { practical methods to the } \\
\text { analysis/ solution of } \\
\text { engineering problems }\end{array}$ \\
\hline
\end{tabular}




\begin{tabular}{|l|l|l|l|}
\hline C & $\begin{array}{l}\text { Accept/ exercise personal } \\
\text { responsibility. }\end{array}$ & $\begin{array}{l}\text { Provide technical/ commercial } \\
\text { management. }\end{array}$ & $\begin{array}{l}\text { Provide technical/ commercial } \\
\text { leadership. }\end{array}$ \\
\hline D & $\begin{array}{l}\text { Use effective communication/ } \\
\text { interpersonal skills. }\end{array}$ & $\begin{array}{l}\text { Demonstrate effective interpersonal } \\
\text { skills }\end{array}$ & $\begin{array}{l}\text { Demonstrate effective } \\
\text { interpersonal skills. }\end{array}$ \\
\hline E & $\begin{array}{l}\text { Make a personal commitment to } \\
\text { an appropriate code of } \\
\text { professional conduct, } \\
\text { recognising obligations to } \\
\text { society/ profession/ environment. }\end{array}$ & $\begin{array}{l}\text { Demonstrate a personal } \\
\text { commitment to professional } \\
\text { standards, recognising obligations } \\
\text { to society/ profession/ environment. }\end{array}$ & $\begin{array}{l}\text { Demonstrate a personal } \\
\text { commitment to professional } \\
\text { standards, recognising } \\
\text { obligations to society/ } \\
\text { profession/ environment. }\end{array}$ \\
\hline
\end{tabular}

Source Engineering Council UK 2008 (adapted)

The other non-humanitarian competence is sector-specific, relating to engineering practice, such as categories $A$ and $B$ in table 2 . Three dimensions can be identified:

- Context - humanitarian, development, high-income country,

- Specialist/ sector/ specific - engineering, health, education,

- Function/generic/ cross cutting - manager, communication skills, personality traits.

\subsection{Specific sector competencies}

Other sectors are also exploring this humanitarian challenge. Meeker, et al. (2013) examined nutrition in emergencies, using core competency frameworks as well as course curricula, job descriptions and interviews. This resulted in a layered pattern (figure 5), with specific nutrition aspects being in the outer layer. However, some humanitarian and functional issues are also included in this specific category, such as familiarity with humanitarian standards, co-ordination, advocacy, reporting and training, as well as some overlap with other sectors, such as logistics.

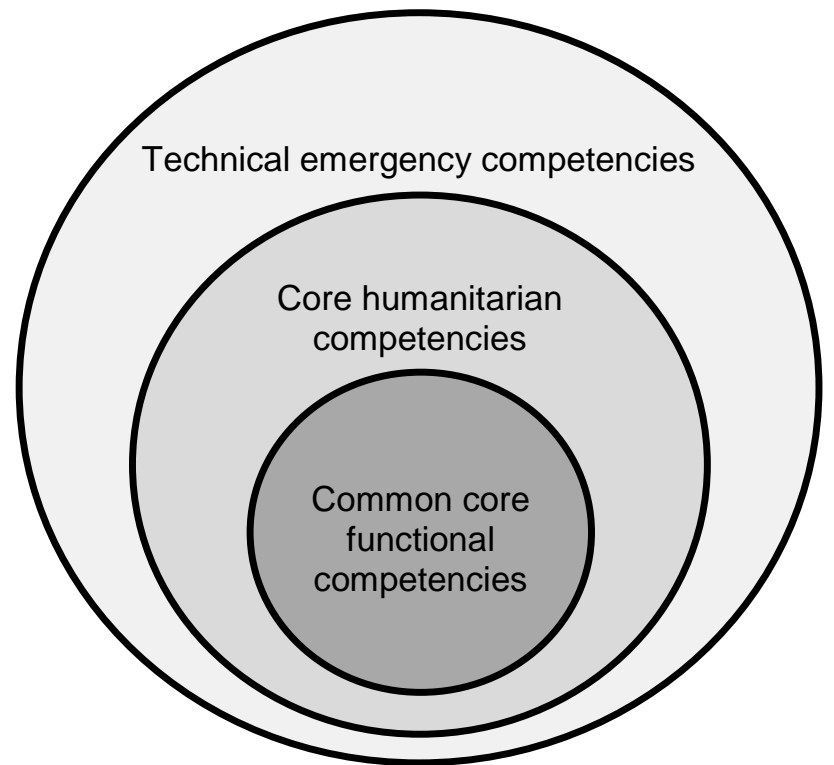

Figure 5: Layered approach to competencies (adapted from Meeker et al 2013)

Within the logistics sector, Kovács et al (2012) used a "T" shaped model, with broad generic skills (management, interpersonal, personality) and deep 'logistics' skills (figure 6), nested within the humanitarian context. Using a similar methodology to Meeker et al (2013), they noted job descriptions were written by 
human resources managers and may not reflect logistics in the field. Kovács et al (2012) identified specific functional roles that do not occur outside the humanitarian context. Liaising with other organisations and training others (even if you are not a trainer but a manager) were important humanitarian logistics aspects. They noted how "standard" logistics has to alter to fit the humanitarian context, with competence in donor relations and regulations replacing the more normal marketing skills. Their sector specific remit also widened, with security being included in the role of a humanitarian logistician.

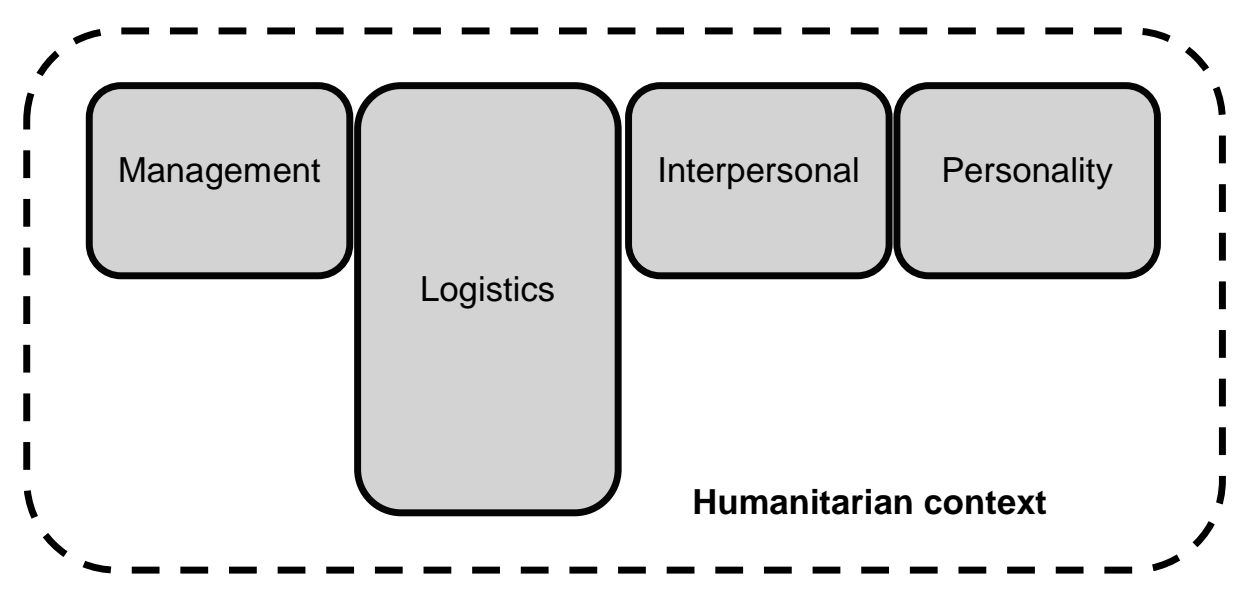

Figure 6: "T" shaped skills profile (adapted from Kovács et al (2012))

Boundaries between humanitarian, functional and specialist competencies are not rigid, with each sector reinterpreting both core humanitarian and generic functional skills. This is also apparent in other contexts; Sansom and Coates (2011) identified management (functional) competencies that relate specifically to urban water supply. Kovács et al (2012) and Meeker et al (2013) also demonstrated that the non-humanitarian specific competencies for logisticians and nutritionists working in other (non-humanitarian) contexts do not provide the level of guidance required for an emergency logistician or nutritionist, although Meeker et al (2013) did note communality between humanitarian and development contexts. Engineering is similar, with many (but not all) aspects of, say, sanitation, being common to disasters and development, but not to stable, developed contexts.

The emerging pattern has overlapping rather than parallel categories (figure 7). A function (like management) has to adapt to the humanitarian context, as do technical skills. Core humanitarian competencies might be reinterpreted differently by sectors, especially where there are similar competencies (e.g. following codes of conduct). This may just be a matter of emphasis, for example, an 'understanding' of the causes of a crisis may not be essential compared with expertise in hydraulics and an 'awareness' of the causes may be adequate. 


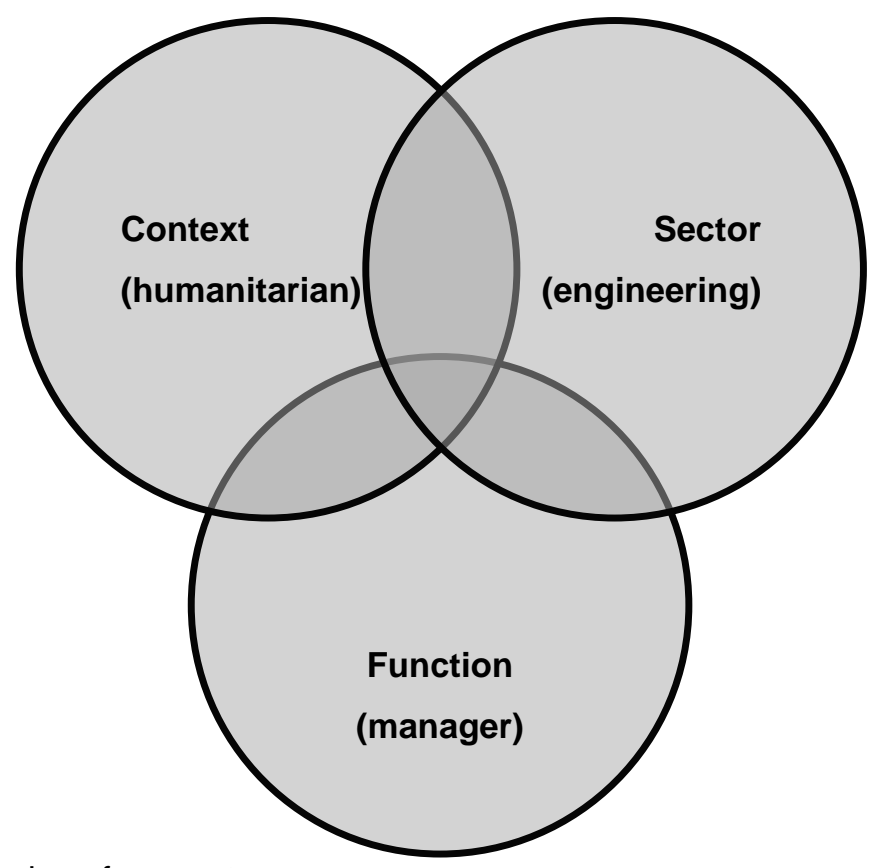

Figure 7. Overlapping domains of competence

\subsection{Different perspectives}

Overlapping perspectives (humanitarian, engineering or human resource function) can result in different expectations.

"Understanding performance is critical to developing appropriate capacity development for the ... sector. Competency requirements that have been developed may differ, depending on who is conducting the analysis - government, donor or [beneficiary] - and this fact matters in determining the effectiveness and value capacity building brings. It is, therefore, important to seek to develop a common understanding of the type of competencies required to manage ... programmes.

(Sansom and Coates, 2011)

Competencies are used by Human Resource Managers to define jobs, assess recruits and identify professional development needs; they are used by training providers to direct courses; they can be used by funders to indicate the quality of an organisation. However, "competency frameworks need to be succinct but sufficiently detailed to give clear indications of the behaviours that are likely to succeed and be rewarded" (Sansom and Coates 2011), so the final perspective must be that of the employee as it is their reality that counts. An example of this is the approach taken by the Chartered Institution of Water and Environmental Management (CIWEM), which was formed from the amalgamation of various institutions working in water and environment, and has members who are engineers, environmentalists, scientists and managers. They have matched CIWEM competencies with the specific requirements of being a chartered engineer, environmentalist or scientist so the candidate for membership can see how each requirement is complementary or distinct (CIWEM, 2013) rather than being faced with a variety of complementary and contrasting requirements. Many competency frameworks have aspects, such as a commitment to on-going learning, that only need to be demonstrated once. 


\section{The challenge of defining humanitarian engineering competencies}

Guidance on what makes a humanitarian engineer is needed by employers and employees, and safeguards those affected by disaster and conflict, but the challenge for the sector is deciding what these competencies should be, requiring expert and varied input. Even the terminology is difficult as it could be viewed that all engineering is "humanitarian" in a wide sense - being for the benefit of society.

\subsection{A global community}

Humanitarian engineering is a global activity, so consensus at internationally, nationally and locally is important. Being inclusive but maintaining quality requires a balanced viewpoint, especially with professionals from varied backgrounds.

\subsection{General or specific?}

"An institution is like a nuclear reactor in that self-exciting activity depends on there being a critical mass of excitable bodies in close proxy

(Hambly 1994)

There needs to be sufficient activity to make competencies relevant. The statement "Apply appropriate theoretical and practical methods to the analysis and solution of engineering problems" (Engineering Council UK 2008) does not provide guidance on what is "appropriate". However, specific water supply, shelter provision or road maintenance performance standards just for emergencies may be too specialised. Meeker et al (2013) noted humanitarian and development technical competencies for nutrition had close similarities, especially after the acute response stage. Looking before the disaster, Bosher et al (2015) noted "increasing acknowledgement of the range of disaster risk reduction issues that need to be more explicitly addressed by practitioners, professional institutions and educators serving the construction sector, ensuring that disaster risk reduction is no longer seen as a niche skill but widely accepted as an important competency."

\subsection{Professional or sectoral?}

Some professions, (e.g. education or health) match directly onto a sector (education or health). The CIWEM example shows that this does not necessarily apply to engineering, where engineers work across several sectors (e.g. water, transport, energy) and work alongside other professionals (e.g. science, planning, architecture). Water, Sanitation and Hygiene (WASH) is a recognised sector within relief, with practitioners expected to address water treatment and distribution as well as environmental sanitation, hygiene promotion and disposal of dead bodies. WASH practitioners have a mixed background, rather than just being a subset of engineers. WASH responsibilities overlap with protection (safe siting of water and sanitation facilities), shelter (drainage and vector control) and health (dead bodies, medical waste and vector control). Thus a WASH practitioner may require considerable non-engineering competencies and may be working more than adequately in some contexts without an engineering qualification. RedR UK have identified skills gaps resulting from increased humanitarian crises in urban areas (Cosgrave, 2013) and this specific context 
requires more engineering skills (e.g. pipe network analysis, advanced water treatment, structural assessment) than a more general WASH workforce can provide.

\section{Towards defining an humanitarian engineer}

\subsection{Putting people at the centre}

The need for competent specialist humanitarian professionals is clear; the details of their competencies are less clear. The contextual (e.g. acute relief, recovery, development, resilience) and sectoral boundaries (e.g. water, shelter, roads) are debateable. Not all professionals in the WASH sector are engineers and not all engineers have the skills to work in WASH. How the humanitarian, functional and specialist competencies interact varies with perspective. However, as Sansom and Coates (2011) noted, the competencies should guide the employee's individual professional development.

Taking an employee-based view therefore, provides a starting point for developing sector competences. Using the WASH categories identified by Sphere (2011) as an example, topics can be identified (table 3). These need to be combined with the functional competencies to introduce the behaviour that is required (e.g. "plan", "analyse", "design", "manage", "identify") and the core humanitarian elements to provide context.

Table 3: Sphere WASH Standards

\begin{tabular}{|c|c|c|c|c|c|c|}
\hline WASH & $\begin{array}{l}\text { Hygiene } \\
\text { promotion }\end{array}$ & $\begin{array}{l}\text { Water } \\
\text { supply }\end{array}$ & $\begin{array}{l}\text { Excreta } \\
\text { disposal }\end{array}$ & $\begin{array}{l}\text { Vector } \\
\text { control }\end{array}$ & $\begin{array}{l}\text { Solid waste } \\
\text { management }\end{array}$ & Drainage \\
\hline \multirow[t]{3}{*}{$\begin{array}{l}\text { WASH } \\
\text { programme } \\
\text { design and } \\
\text { implementation }\end{array}$} & $\begin{array}{l}\text { Hygiene } \\
\text { promotion } \\
\text { implementation }\end{array}$ & $\begin{array}{l}\text { Access } \\
\text { and } \\
\text { water } \\
\text { quantity }\end{array}$ & $\begin{array}{l}\text { Environment } \\
\text { free from } \\
\text { human faeces }\end{array}$ & $\begin{array}{l}\text { Individual } \\
\text { and family } \\
\text { protection }\end{array}$ & \multirow[t]{3}{*}{$\begin{array}{l}\text { Collection and } \\
\text { disposal }\end{array}$} & \multirow[t]{3}{*}{$\begin{array}{l}\text { Drainage } \\
\text { work }\end{array}$} \\
\hline & \multirow[t]{2}{*}{$\begin{array}{l}\text { Identification } \\
\text { and use of } \\
\text { hygiene items }\end{array}$} & $\begin{array}{l}\text { Water } \\
\text { quality }\end{array}$ & \multirow[t]{2}{*}{$\begin{array}{l}\text { Appropriate } \\
\text { and adequate } \\
\text { toilet facilities }\end{array}$} & $\begin{array}{l}\text { Physical, } \\
\text { environ- } \\
\text { mental and } \\
\text { chemical } \\
\text { protection } \\
\text { measures }\end{array}$ & & \\
\hline & & $\begin{array}{l}\text { Water } \\
\text { facilities }\end{array}$ & & $\begin{array}{l}\text { Chemical } \\
\text { control } \\
\text { safety }\end{array}$ & & \\
\hline
\end{tabular}

(Source Sphere 2011)

\subsection{Bringing people together}

Sansom and Coates (2011) identified the importance of a common understanding, so competencies need to be inclusive and "owned" by the profession as a whole. The examples of work-based (CBHA) and universitybased (EUPHRA) initiatives having different priorities and assessment criteria demonstrated that both should be involved, but they have their own perspectives.

In 1994, Edmund Hambly noted in his ICE presidential address

"We could do more to help society understand the capabilities and skills of civil engineers. All civil engineers are expected to have background ' awareness' of the various technologies and professions to 
which their work relates and 'competence' in their own particular field, including knowing the limitations of themselves and others. Key personnel are expected to have 'expertise' in their roles of management and technical responsibility. The Engineering Boards and Associated Societies ferment specialist knowledge and technology foresight, but we have no accessible records of the specialist skills of members (except for reservoirs) to assist the public drawing on this knowledge. If we wish society to value our skills we must make available registers of specialist skills to demonstrate the value we put on them ourselves."

(Hambly 1994)

Since 1994, the ICE now has registers (ICE, no date), such as

- Ground Engineering Professionals, in partnership with the Geological Society of London and the Institute of Materials, Minerals and Mining;

- Conservation Engineers (historic buildings), in partnership with the Institution of Structural Engineers;

- Health and Safety;

- Security Engineers and Specialists; and

- Dispute resolution.

These have different grades of expertise (e.g. Ground engineering professional, specialist or adviser), different areas of expertise within each discipline (e.g. contaminated land, engineering geology, foundations or underground works) and work in partnership with similar organizations. CIWEM has a less formal approach, with "groups" of people working in similar fields (rivers and urban drainage) and "networks" of common interest (e.g. energy, natural capital, climate change, the arts) organising activities.

\section{$5.3 \quad$ Next steps}

This paper provides the rationale for recognising the specific skills of engineering professionals in the humanitarian field, describing current initiatives, concepts, challenges and ways that may be useful in providing a sustainable framework. It does not have all the answers however, as this needs a wider debate. Whilst a set of competencies is valuable for employers, these also enable professionals to benchmark their own level of knowledge and expertise, so they can judge if they are competent to offer expert humanitarian assistance.

\section{Acknowledgements}

The authors would like to acknowledge the work of the wider humanitarian sector, but in particular the discussions with colleagues that took place at the Centre for Education and Research in Humanitarian Action (CERAH) Conference on "Humanitarian Education and Training", Geneva, Switzerland in October 2011. Thanks to lan Smout of WEDC and Harriette Purchas of RedR UK for providing comments on the paper.

\section{References}

Aardema B.L. and Muguruza, C.C. (2014) The Humanitarian Action Qualifications Framework: a quality assurance tool for the Humanitarian Sector. Tuning Journal for Higher Education Volume 1 (2) pp 429-462 
Bosher L., Cassidy Johnson, C. and Von Meding, J. (2015) Reducing disaster risk in cities: moving towards a new set of skills Proceedings of the ICE - Civil Engineering, 168(3), pp $99-99$

Bourn, D and Neal, I (2008) The Global Engineer : Incorporating global skills within UK higher education of engineers. Engineers Against Poverty/ Development Education Research Centre, Institute of Education, University of London, London UK

Carr, M (1985) The AT reader: theory, practice in appropriate technology Intermediate Technology London UK CHS (2014) Core Humanitarian Standard on Quality and Accountability Groupe URD, HAP International, People In Aid and the Sphere Project. \{available on-line\} http://www.corehumanitarianstandard.org/ (viewed November 2015)

Cosgrave, J. (2013) Ready to Respond: Skills gaps for responding to humanitarian crises in urban settings in the WASH and shelter sectors. RedR UK, London UK

CIWEM (2013) 14 Mandatory Competencies of CIWEM to the Engineering Council; Society for the Environment and Science Council \{available on-line\} http://www.ciwem.org/membership/apply-formembership/chartered-member-mciwem-cwem.aspx registers [viewed June 2015]

Davis, J., \& Lambert, R. (2002). Engineering in Emergencies - A Practical Guide for Relief Workers. 2nd edition Intermediate Technology Publications Ltd. London, UK:

Emmens, B., Richardson, L., Chisholm, M. and Swords, S. (no date). Programme Guide. Context: Humanitarian Staff Development Project Start Network, London UK http://www.contextproject.org/pdfs/programme-guide.pdf (accessed on 02/02/2016)Engineering Council (2008) UK Standard for Professional Engineering Competence Engineering Council, London UK

EWB (no date) Engineers without Borders \{available on-line\} http://www.ewbchallenge.org/content/aimsobjectives [viewed June 2015]

Ferguson H and Chrimes M (2011) The Civil Engineers: The Story of the Institution of Civil Engineers and the People Who Made It ICE Publishing, London UK

Hambly E (1994) Presidential Address. Advancing Civil Engineers. Proceedings of the ICE - Civil Engineering, 102 (4) pp $142-144$

Herlinger C (2009) With Courage, In Hope: Five Years after the Tsunami ACT International Geneva Switzerland

ICE (2014) Royal Charter, By-laws, Regulations and Rules Institution of Civil Engineers, London UK \{available on-line\} https://www.ice.org.uk/ICEDevelopmentWebPortal/media/Documents/About\%20Us/ice-royalcharter-and-by-laws.pdf [viewed June 2015]

ICE (no date) Specialist professional registers \{available on-line\} https://www.ice.org.uk/careers-andprofessional-development/careers-advice-for-civil-engineers/specialist-professional-registers [viewed June 2015]

ICE (2015) ICE Training Scheme and Guidance Institution of Civil Engineers, London UK ICE Capacity Building Panel, (2011), Competency Framework for Professional Development, Institution of Civil Engineers, London UK.

Jowitt P.W. (2004) Sustainability and the formation of the civil engineer Proceedings of the ICE - Engineering Sustainability, 157 (2), pp $79-88$

Korff, V. P., Balbo, N., Mills, M., Heyse, L. and Wittek, R. (2015), The impact of humanitarian context conditions and individual characteristics on aid worker retention. Disasters, 39 (3): pp 522-545. 
Kovács, G., Tatham, P. and Larson, P. D. (2012), What Skills Are Needed to be a Humanitarian Logistician?. Journal of Business Logistics, 33 (3):pp245-258.

Meeker, J., Perry, A., Dolan, C., Emary, C., Golden, K., Abla, C., Walsh, A., Maclaine, A. and Seal, A. (2013) Development of a competency framework for the nutrition in emergencies sector. Public Health Nutrition: 17(3), 689-699

PHAP (no date) Professionals in Humanitarian Assistance and Protection \{available on-line\} https://phap.org/ [viewed June 2015]

Rainhorn J-D., Smailbegovic, A. and Jiekak, S. (2010) University Training and Education In Humanitarian Action/ Formations Universitaires en Action Humanitaire Centre d'enseignement et de recherché en action humanitaire de Genève - CERAH. Geneva Switzerland

Reed, B.J., Coates, S. Odhiambo, F. Kayaga S. (2011) Training for real: matching employer needs to training supply Proceedings of the ICE - Municipal Engineer, 164(4), pp $269-278$

Rutter L, Swords, S., Price, M., Emmens, B. (2011) Core Humanitarian Competencies Guide: Humanitarian Capacity Building Throughout the Employee Life Cycle. ActionAid, London UK

Sansom, KR and Coates, S (2011) Developing competencies for water utility change programmes, Proceedings of the Institution of Civil Engineers: Municipal Engineer, 164(4), pp.259-268,

The Sphere Project (2011) Humanitarian Charter and minimum standards in humanitarian response The Sphere Project/Practical Action Publishing Geneva, Switzerland

Walker, P. and Russ, C. (2010) "Professionalising the Humanitarian Sector" ELRHA (Enhancing Learning and Research for Humanitarian Assistance) London UK

Figure captions

Figure 1. Carrying out social surveys are an essential part of site investigation. (photo B.J. Reed)

Figure 2. Disaster preparedness training, Liberia (photo B.J. Reed)

Figure 3. RedR UK Theory of Professional Development.

Figure 4. Results chain applied to training and professional development (source WEDC)

Figure 5. Layered approach to competencies (adapted from Meeker et al 2013)

Figure 6. "T" shaped skills profile (adapted from Kovács et al (2012))

Figure 7. Overlapping domains of competence 